\title{
Research on the Management Model of Tourism Exhibition in China under the New Situation
}

\author{
Qian Chen \\ Chongqing College of Finance and Economics, Chongqing, 402160, China
}

\author{
Keywords: Management Model, Tourism Exhibition, New Situation
}

\begin{abstract}
In the academic theory world, many researchers have no unified views on the deep understanding of the concept of "convention tourism", but there are different opinions. Exploring the management mode of China's tourism exhibitions under the historical background of tourism exhibition development, and analyzing various research viewpoints will greatly promote the development of China's exhibition management mode. At the beginning of the paper, the concept, characteristics and functions of MICE tourism under the new situation are introduced. Then, it introduces some problems that we should pay attention to under the new situation. Finally, it introduces the management mode of tourism exhibition in China under the new situation of government leading, association self-discipline, business operations and social participation.
\end{abstract}

\section{Introduction}

MICE tourism is a new concept that has emerged in recent years. Fresh words, in other words, related conferences and exhibitions, but when we combine "tourism" with exhibitions, the meaning is no longer literal. And has a new connotation. By studying the past tourism exhibition development model and its outstanding achievements, it has important reference and guidance. However, there are many viewpoints in the academic world, including: First, MICE is a special tourism product or an emerging tourism model, and the exhibition industry is part of the tourism industry. The second view is that MICE tourism is a kind of new industry in which the exhibition industry and the tourism industry interact positively and interact with each other and combine with each other. Various opinions are widely divided. Based on this research, China's MICE tourism management model must be carried out after understanding the specific concepts and various characteristics and possible problems.

\section{Overview of tourism exhibitions}

MICE tourism is a form of business travel, which is a tourism service that is held during conferences, forums, seminars, and other exhibitions. There are two definitions of exhibition tourism in a broad sense and a narrow sense. The general exhibition tour refers to the main purpose of holding conference activities and various exhibitions. Tourism is an accessory of conference activities and exhibitions. It is for the purpose of conference activities and exhibitions. Tourism carried out; narrowly defined exhibition tourism refers to the tourism services provided together with the conference activities and exhibitions, and is linked to certain economic interests. MICE tourism can not only bring cultural exchanges and communication to the tourist destinations, but also introduce science and technology. At the same time, it can also promote the development of local tourism and promote the development of the local economy. Exhibitions and tourism are two different industries, but the two are highly related. The holding of conference activities and exhibitions will promote the development of local catering and hotel services, and will also promote the development of the local transportation industry. Of course, it will also raise the local reputation to a certain extent. It can be said that the integration of exhibition and tourism is the need of social development. MICE tourism is the result of diversified development of the industry. The exhibition industry brings tourism to the tourism industry. In turn, tourism can promote the development of the local convention and exhibition industry. The two promote each other and develop each other. 
High-profile conference activities and exhibitions are an opportunity for many people to relax and have a long-term experience, which will enable people to have a high degree of enthusiasm to participate in tourism, which will promote relevant conference activities and economic development in the exhibition area. It will promote the development of the local catering industry, hotel service industry, tourism and transportation, and will also enhance the city's functions and greatly increase the reputation of the local tourism industry. MICE tourism can eliminate the obvious shortcomings of the general tourism time, regardless of the season and climate. Under normal circumstances, high-profile conference activities and exhibitions will be held in the off-season of tourism, so as to avoid the situation of too many tourists causing chaos in the local tourism industry. Choosing in the off-season can improve the utilization of tourism services and facilities in the local tourism industry, and there will be no bleak business. The six elements of tourism refer to "eat, live, travel, travel, purchase, and entertainment". The economic benefits of tourism are mainly generated by these six factors. High-level conference activities and exhibitions meet the six elements of tourism. Drive the development of tourism. At the same time, the advantages accumulated by the tourism industry in the historical development can provide corresponding services for the event activities and exhibitions, launch the brand of the exhibition, and promote the development of the exhibition industry. In the form of tourism such as MICE tourism, the tourism industry and the convention and exhibition industry each perform their duties and work together. The exhibition industry is mainly responsible for the recruitment, publicity, exhibition and organization and management of the exhibition, while the tourism industry is mainly responsible for participating in the conference activities. And the life of the exhibition staff, to provide them with the six elements involved in the tourism industry, so that exhibitors and participants can work and live together, travel at the same time as work, relax, do not relax when traveling jobs. In this way, exhibitors, tourists and local residents have achieved the greatest effect through MICE tourism.

\section{Insufficient management aspects of tourism exhibitions in the new era}

The development of tourism exhibitions is not very long. The way to manage tourism exhibitions has only begun. Therefore, there are many shortcomings that have a great impact on the development of tourism. The important shortcomings are: First, the immature management methods have been investigated. We can see that tourism exhibitions are still in a new era, lack of sound management methods, and no sound rules and regulations, so there will be many problems in the management. Second, the direction of guidance is not clear enough. The rise of tourism exhibitions is not long, the development is too fast, there is no department that can be directly managed, and the relevant departments have no clear regulations on specific management rules, so there is no clear direction to guide the development of tourism. Finally, there is a lack of rich tourism projects. After research, we got most people to visit the exhibition just to appreciate and watch. Therefore, there are not many people who travel and other tourism projects, which wastes the resources of tourism and leads to lower economic benefits. Although China will combine the exhibition industry with the tourism industry, it has a small market share. The combination of convention and exhibition industry and tourism is still not complete, and there is still a long way to go. In terms of management, there is no unified planning, the functions of various departments are not clear, and there is no special management organization. In operation, MICE needs cooperation between exhibition companies and tourism companies, so that the government will have certain difficulties in organizing; The personnel are mainly limited to attending exhibitions, and spontaneous groups are rarely visited, shopping, and entertainment. At the same time, the tourism industry provides too little tourism services to the convention and exhibition industry, and more is transportation, hotel services and catering services, resulting in good economic benefits in the transportation industry, hotel service industry and catering industry, while the economic benefits of entertainment shopping are poor. 


\section{Research on the Management Model of Tourism Exhibition in China under the New Situation}

MICE tourism can promote the rapid development of regional economy and is a major driving force for regional economic development. Based on this, local governments are competing to develop MICE tourism in the region, formulate rules and regulations related to MICE tourism, and employ high-paying professionals to form a special research group to discuss the development model of MICE tourism. Governments in many regions have already led research related topics, such as the North, Guangzhou and other regions. However, there are some drawbacks in the government-led research process, such as excessive government participation and too complicated forms, which lead to the government-led research topics failing to achieve the desired results. And the rules and regulations formulated by the government departments are not perfect enough, and the relevant laws and regulations must be further improved on this basis. 2. Under the leadership of the government, all associations have begun to establish exhibition associations spontaneously. In many areas, such as Beijing, Shanghai, Guangzhou, Wuhan and other places have established exhibition associations, the earliest established in Beijing, was established at the end of the last world. Various industries or various types of personnel can communicate through the exhibition association, and the exhibition association provides a platform for sharing various types of information. Each enterprise department can impart development experience to each other, and the associations can also exchange ideas, learn from each other's strengths, improve themselves, and supervise and promote each other. The association is a self-disciplined organization, and members must abide by the relevant regulations of the association, which can play a certain role in restraining relevant departments.

Under the leadership of the government, enterprises must also actively cooperate and contribute their own strength. Enterprises should make good use of the opportunities created by the government and associations, actively participate in and vigorously develop themselves. All enterprises must respond to the government's call, work hard to build exhibition venues, establish various conference rooms and commercial centers, and lay the foundation for various conference activities and exhibitions. At the same time, the society should also actively participate in it. The strength of the masses is endless. They have rich wisdom and can make suggestions for the government's management model of tourism. At the same time, the work of the government, enterprises and associations needs all levels of society. Strong support and the ability of the society to monitor the operations of all units, including governments, businesses and associations. By mobilizing social forces and uniting people from all walks of life, we can promote the development of China's MICE tourism more quickly. All provinces and cities in various regions began to establish self-disciplined industry associations. The regions began to establish convention associations under the leadership of the government. The Beijing International Conference and Exhibition Industry was formally established in June 1998. This also brought a good head to the society and played an exemplary role. After that, many places began to follow the example of Beijing, so in 2002 Shanghai also established an industry association. Subsequently, Guangzhou, Zhejiang, Shandong and Wuhan also gradually established industry associations. The emergence of industry associations not only provides a platform for exchanges between enterprises, but also enables business representatives and relevant industry insiders to conduct effective exchanges and cooperation, promote information sharing, and also play a role in tourism management. Certain positive effects. Through the self-discipline of the association, it can effectively regulate the business management behavior within the enterprise, strictly manage according to the rules and regulations established within the association, and greatly promote the research on the internal management of each association. At the same time, each association can also learn from each other's excellent management experience and some development achievements through mutual exchanges, mutual reference and mutual supervision, and give full play to the role of the association.

Social participation. Only the strength of government association enterprises is far from enough, and it requires extensive and active participation from the whole society. The strength of the masses 
is endless, and members of society also have a wealth of wisdom, and in many cases can put forward very good opinions and suggestions. On the one hand, the wide participation of the society can strengthen the supervision of the operation of the enterprise, so that it does not dare to slack off, and does not dare to corrupt and degenerate, so that with the participation of the society, it can improve management efficiency; on the other hand, the extensive participation of society It will form a good social atmosphere and further stimulate government enterprises to continuously explore new management modes and ways of tourism exhibitions, improve the enthusiasm of all aspects, concentrate on strengths, and form a virtuous circle, so that all members can share the beneficial results of tourism exhibitions. .

\section{Conclusion}

MICE tourism is a new type of tourism. Because of its huge economic benefits and the resulting social benefits, it has gradually become the highlight of tourism development. Its attention is increasing, so it is very valuable to study this topic under the new situation. The article introduces the basic concepts of MICE tourism, features and analyzes the development prospects of the industry, and focuses on the management mode of China's tourism exhibitions under the new situation, that is, government-led, association self-discipline, business operation, and social participation.

\section{References}

[1] Zhang Chao, Li Qingman. Innovation of tourism exhibition management mode in the new economic era [J]. Management and Management, 2017 (5): 35-37.

[2] Wang Xingdan. Research on the Management Model of Tourism Exhibition in China under the New Situation [J]. Modernization of Shopping Malls, 2015(27): 255-256.

[3] Wang Yan. Research on the Management Model of Tourism Exhibition in China under the New Situation [J]. Tourism Overview, 2015(3): 40-41.

[4] Zhang Xianchun. Reflections on the Training of Professional Talents in Tourism Exhibition and the Construction of Curriculum System [J]. Journal of Guilin College of Tourism, 2015(04): 32-36.

[5] Tan Huayun, Huang Yihu. On the role of the main body of the tourism exhibition and exhibition system in the transition period [J]. Business Times, 2009 (05): 121-122. 